\title{
Zirconia sol-gel coatings deposited on 304 and 316L stainless steel for chemical protection in acid media
}

\author{
M. ATIK, S. H. MESSAdDEO, F. P. LUNA, M. A. AEgERTER \\ Institute of Physics of São Carlos, University of São Paulo, Cx. Postal 369-13560-970 - São Carlos (SP), Brazil
}

Corrosion resistance is one property that many industries require for materials that are used in their equipment and components. Some researches have reported on corrosion behaviour in aqueous acid or basic solutions of steels, metals and alloys protected by sol-gel coatings [1-4]. Sol-gel films of zirconia, silica and mixed oxides of $\mathrm{SiO}_{2}-\mathrm{TiO}_{2}$ and $\mathrm{SiO}_{2}$ $\mathrm{Al}_{2} \mathrm{O}_{3}$ prepared by dip-coating using sonocatalysed sols have been shown as promising coatings to prevent against corrosion of stainless steel [5-10]. All these inorganic films improve the chemical and physical properties and increase the protection of metal substrates from air corrosion, basic and acid attack.

The aim of this work is the preparation of $\mathrm{ZrO}_{2}$ films coated on 304 and $316 \mathrm{~L}$ austenitic stainless steel (SS) substrates, materials widely used for marine and chemical industry environments, and deposited by a dip-coating technique using a sol preparation involving sonocatalysis. The sols were obtained by hydrolysis and polymerization of $\mathrm{Zr}$ alkoxide, $\mathrm{Zr}\left(\mathrm{OC}_{3} \mathrm{H}_{7}\right)_{4}$, dissolved in alcohol, $\mathrm{C}_{3} \mathrm{H}_{7} \mathrm{OH}$, acetic acid, $\mathrm{CH}_{3} \mathrm{COOH}$, and water solutions. This technique leads to the development of homogeneous sols for gel coatings without cracks. The corrosion characteristics of the samples were evaluated through potentiodynamic polarization curves measured in $15 \% \mathrm{H}_{2} \mathrm{SO}_{4}$ solutions at room temperature.

Zirconium propoxide, $\mathrm{Zr}\left(\mathrm{OC}_{3} \mathrm{H}_{7}\right)_{4}$, was used as the source of zirconia. The sol was prepared by diluting the alkoxide in isopropanol, $\mathrm{C}_{3} \mathrm{H}_{7} \mathrm{OH}$, to which was added glacial acetic acid, $\mathrm{CH}_{3} \mathrm{COOH}$, as catalyst and distilled water. The concentration of the starting alkoxide solution was $0.5 \mathrm{moll}^{-1}$ and the volume ratios of $\mathrm{H}_{2} \mathrm{O}: \mathrm{C}_{3} \mathrm{H}_{7} \mathrm{OH}$ and $\mathrm{H}_{2} \mathrm{O}: \mathrm{CH}_{3} \mathrm{COOH}$ were 1 and 2, respectively. The solution was homogenized with ultrasound irradiation produced by a transducer immersed in the mixture (Heat Systems Ultrasonics W 385 Sonicator, $20 \mathrm{kHz}$ ). After hydrolysis the resulting sols were clear, transparent and stable for five weeks at room temperature.

The substrates used in the experiments were 304 and $316 \mathrm{~L}$ austenitic stainless steels, their chemical compositions (wt \%) are shown in Table I. These materials were chosen, taking into account the heat treatment necessary for densification of the coatings, because the materials have low carbon contents and are less susceptible to sensitization that promotes enhanced corrosion. Chemical analyses of the samples show that $304 \mathrm{SS}$ has less amounts of Mo $(0 \mathrm{wt} \%)$. The specimens were machined into the dimensions of $30 \times 20 \times 0.4 \mathrm{~mm}$, degreased ultrasonically in acetone and rinsed with distilled water. They were dipped into the solution and withdrawn at a speed of $10 \mathrm{~cm} \mathrm{~min}^{-1}$. The gel coated SS were dried in ambient atmosphere for $15 \mathrm{~min}$ at $60{ }^{\circ} \mathrm{C}$ and then densified in a furnace in air atmosphere, increasing the temperature at a rate of $5^{\circ} \mathrm{Cmin}^{-1}$ with two isothermal holdings, first at $450{ }^{\circ} \mathrm{C}$ for $1 \mathrm{~h}$ and then at $800^{\circ} \mathrm{C}$ for $2 \mathrm{~h}$ in air to obtain adherent and dense coatings. Their thicknesses measured by ellipsometry, varied between 0.35 to $0.8 \mu \mathrm{m}$, depending on the sol concentration. The average thickness of the heat-treated film at $800{ }^{\circ} \mathrm{C}$ was around $0.5 \mu \mathrm{m}$.

$\mathrm{X}$-ray diffraction patterns of the coatings were recorded with a Philips diffractometer with a $\mathrm{Cu} \mathrm{K}$ irradiation (wavelength, $\lambda=0.15418 \mathrm{~nm}$ ). A Bomen Fourier transform infrared (FTIR) analyser was used to obtain high resolution optical reflection spectra of the coatings in the range $400-4000 \mathrm{~cm}^{-1}$ at an incident angle of $30^{\circ}$.

For the corrosion, the potentiodynamic polarization curves for each of the test specimens were carried out in deareated $15 \% \mathrm{H}_{2} \mathrm{SO}_{4}$ at $25{ }^{\circ} \mathrm{C}$ using a computerized PAR model 273 potentiostat/galvanostat; the geometric areas of the specimens under evaluation were similar. A saturated calomel electrode (SCE) was used as reference and a $\mathrm{Pt}$ foil served as the auxiliary electrode. The working electrodes were 304 or $316 \mathrm{~L}$ SS plates, either bare or coated, immersed $1 \mathrm{~cm}$ into the solution. The potentiodynamic measurements were initiated at $-1.0 \mathrm{~V}$ versus the SCE and scanned continuously in the anodic direction at a rate of $1 \mathrm{mV} \mathrm{s}^{-1}$. The data were analysed with PAR model 352 Corrosion Measurements software.

TABLE I Chemical composition of 304 and $316 \mathrm{~L}$ austenitic stainless steel (wt \%)

\begin{tabular}{llllllll}
\hline Substrate & Fe & Cr & Ni & Mo & Mn & Si & C \\
\hline SS 304 & 70.94 & 18.59 & 8.16 & - & 1.74 & 0.45 & 0.070 \\
SS 316L & 67.25 & 18.55 & 11.16 & 2.01 & 1.70 & 0.15 & 0.028 \\
\hline
\end{tabular}


The diffractograms of SS 304 and 316L show the existence of a crystalline phase with $d$ values of $0.208,0.180$ and $0.127 \mathrm{~nm}$ that correspond to the cubic phase of the alloy containing $\mathrm{Cr}, \mathrm{Fe}$ and $\mathrm{Ni}$ (Fig. 1a). When both substrates are heated at $800{ }^{\circ} \mathrm{C}$ for $2 \mathrm{~h}$ in air, the first peak decreases in intensity and other peaks appear with $d=0.364,0.267$ and $0.25 \mathrm{~nm}$, corresponding to the formation of cubic and hexagonal $\mathrm{Cr}_{2} \mathrm{O}_{3}$ (Fig. 1b).

Besides the three diffraction peaks of stainless steel, the substrates coated with $\mathrm{ZrO}_{2}$ heated at $800{ }^{\circ} \mathrm{C}$ in air for $2 \mathrm{~h}$ show one additional peak with $d=0.298 \mathrm{~nm}$, corresponding to tetragonal zirconia. As no change was observed in the relative intensities of the peaks of the alloy, it can be concluded that no oxidation of the coated samples occurred during heat treatment. Details of these analysis can be found elsewhere (Fig. 1c).

Infrared (i.r.) spectra of unsintered coated samples show bands characteristic of $\mathrm{OH}^{-}$at $\sim 3600 \mathrm{~cm}^{-1}$, $\mathrm{Zr}-\mathrm{O}-\mathrm{C}$ groups at 1476.8 and $1452.8 \mathrm{~cm}^{-1}$, and $\mathrm{Zr}-\mathrm{O}-\mathrm{Zr}$ at $665.7 \mathrm{~cm}^{-1}$ (Fig. 2a). During sintering,

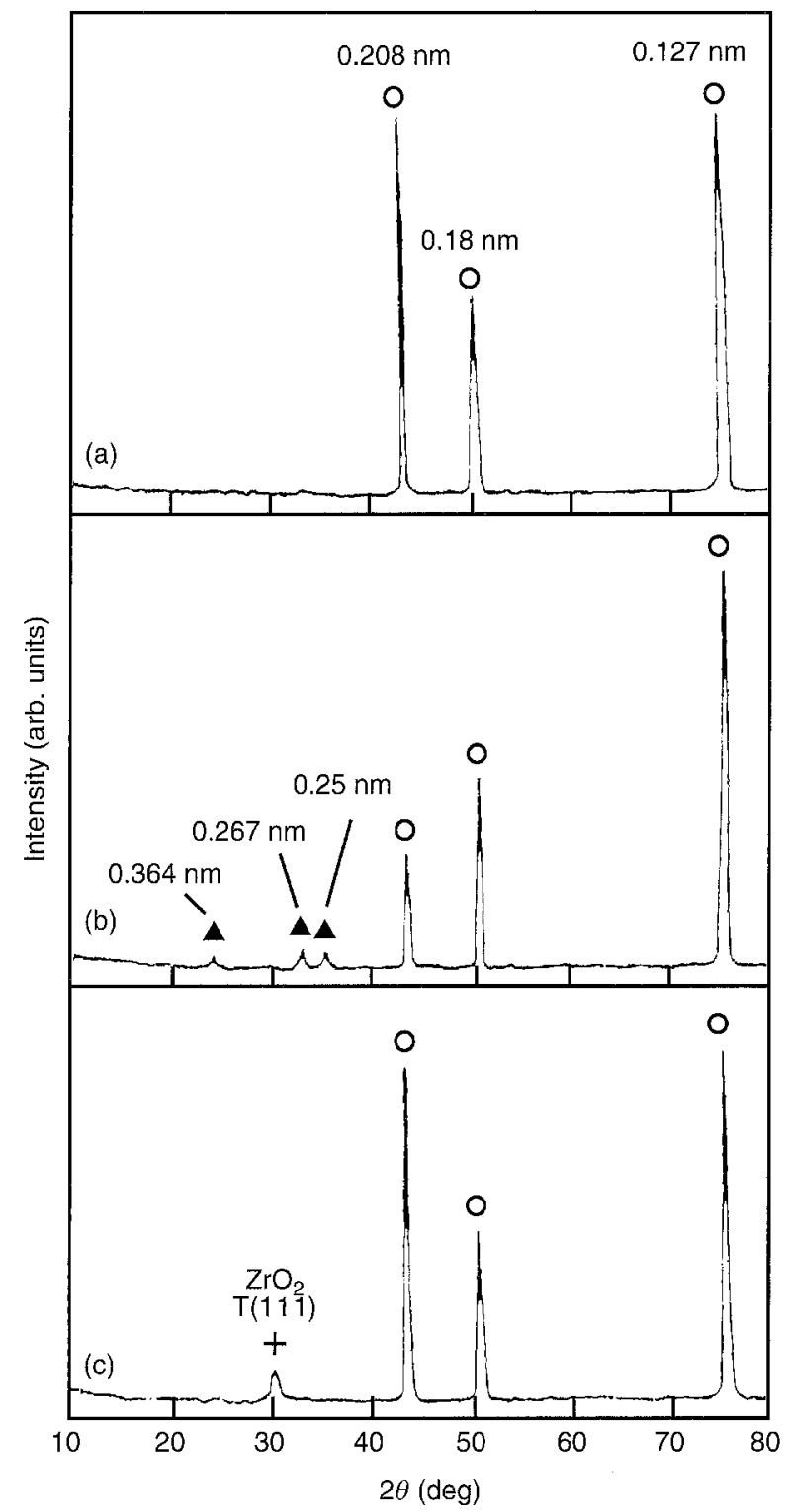

Figure I XRD patterns of uncoated and coated substrates: stainless steel (a) as-received, (b) heat treated at $800^{\circ} \mathrm{C}$ in air atmosphere for $2 \mathrm{~h}$, (c) coated with $\mathrm{ZrO}_{2}$ film and heat treated in atmosphere for $2 \mathrm{~h}$.

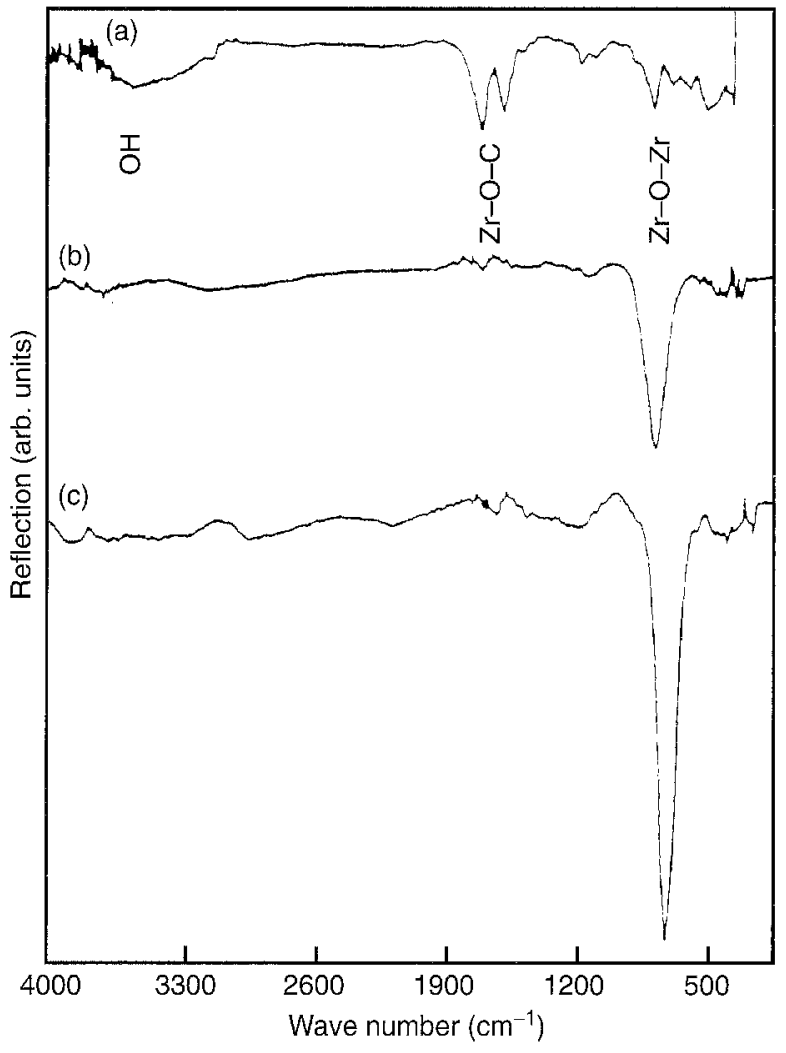

Figure 2 I.r. spectra of $\mathrm{ZrO}_{2}$ films deposited on stainless steel: (a) asdried at $25^{\circ} \mathrm{C}$, (b) after firing at $450^{\circ} \mathrm{C}$ for $2 \mathrm{~h}$, and (c) after oxidation in air at $800^{\circ} \mathrm{C}$ for $2 \mathrm{~h}$.

the $\mathrm{OH}^{-}$and $\mathrm{Zr}-\mathrm{O}^{-}-\mathrm{C}$ bands disappear and the $\mathrm{Zr}-$ $\mathrm{O}-\mathrm{Zr}$ band increases strongly (Fig. $2 \mathrm{~b}, \mathrm{c}$ ).

Figs 3 and 4 show typical potentiodynamic polarization curves obtained for the samples under investigation in deareated $15 \%$ sulphuric acid solution at room temperature. The curves were

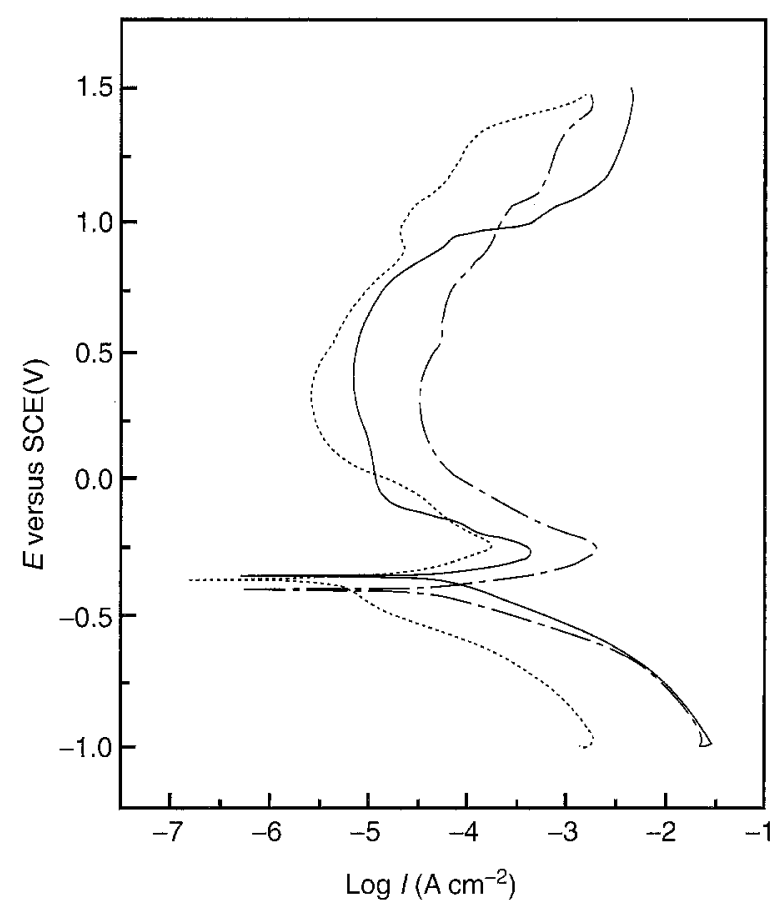

Figure 3 Potentiodynamic polarization curves measured in deareated $15 \%$ aqueous $\mathrm{H}_{2} \mathrm{SO}_{4}$ for 304 stainless steel: $(-)$ uncoated and untreated, $(\cdot-\cdot)$ uncoated but heat-treated at $800^{\circ} \mathrm{C}$ for $2 \mathrm{~h}$, and $(--)$ coated with $\mathrm{ZrO}_{2}\left(800^{\circ} \mathrm{C}_{2} \mathrm{~h}^{-1}\right)$ at $25^{\circ} \mathrm{C}$. 


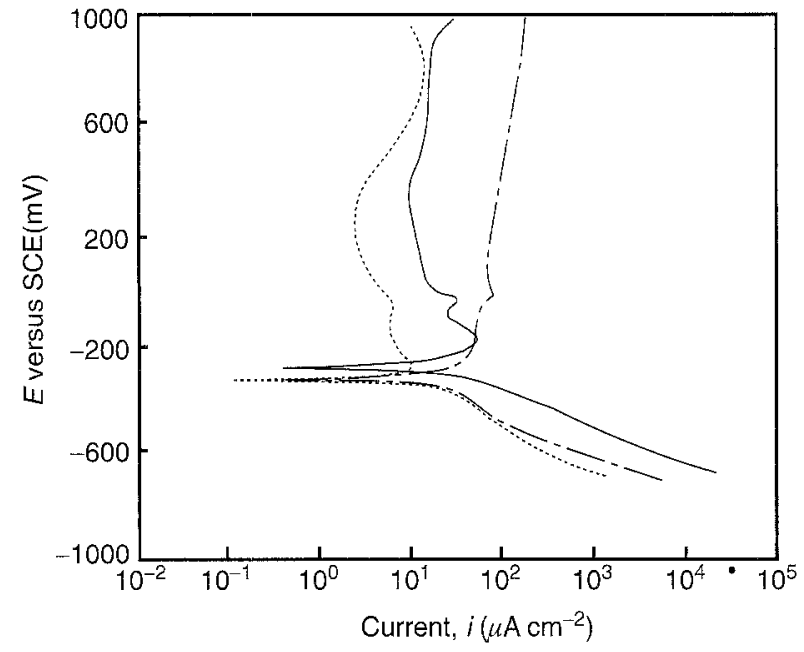

Figure 4 Potentiodynamic polarization curves measured in deareated $15 \%$ aqueous $\mathrm{H}_{2} \mathrm{SO}_{4}$ for $316 \mathrm{~L}$ stainless steel: $(-)$ uncoated and untreated, (.- ) uncoated but heat-treated at $800^{\circ} \mathrm{C}$ for $2 \mathrm{~h}$, and $(---)$ coated with $\mathrm{ZrO}_{2}\left(800{ }^{\circ} \mathrm{C}^{2} \mathrm{~h}^{-1}\right)$ at $25^{\circ} \mathrm{C}$.

recorded a few minutes after immersion of the samples in order to allow stabilization of the system. In all cases, the cathodic branch of the curves corresponds to the hydrogen evolution reaction, controlled by the Volmer-Heyrovsky reaction mechanism [11]. The slope of the curves for uncoated and untreated substrates is $\sim 2.3 \times 2 R T / F$, where $R$ is the universal gas constant, $T$ the temperature and $F$ the Faraday constant. In the presence of the coatings, the value of the slope is maintained, suggesting that the reaction mechanism remains unchanged. The anodic branches show that the coatings have a strong effect on the current density in the passive region, reducing substantially the current value.

The corrosion current at zero applied potential was extrapolated from these plots and used to calculate the corrosion rate (CR) in mils per year (mpy).

Table II collects the electrochemical parameters obtained for uncoated and coated substrates in $\mathrm{H}_{2} \mathrm{SO}_{4}$. It it noticeable that the corrosion rate for coated substrates is about seven times lower than that of uncoated substrates and the polarization resistance seven times higher. However, the corrosion potential, $-E_{\mathrm{c}}$, which is a measure of 361 and

TABLE II Corrosion parameters determined from the potentiodynamic curves measured for stainless steels 304 and $316 \mathrm{~L}$ asreceived, uncoated but heat-treated at $800^{\circ} \mathrm{C}$ for $2 \mathrm{~h}$ and coated with $\mathrm{ZrO}_{2}\left(800^{\circ} \mathrm{C} 2 \mathrm{~h}^{-1}\right)$

\begin{tabular}{llll}
\hline Sample & $\begin{array}{l}\text { Corrosion } \\
\text { potential, } \\
-E_{\mathrm{c}} \\
(\mathrm{mV})\end{array}$ & $\begin{array}{l}\text { Polarization } \\
\text { resistance, } \\
R_{\mathrm{p}} \\
\left(\mathrm{k} \Omega \mathrm{cm}^{2}\right)\end{array}$ & $\begin{array}{l}\text { Corrosion } \\
\text { rate, } \\
\mathrm{CR} \\
(\mathrm{mpy})\end{array}$ \\
\hline As-received & & & \\
$\mathrm{SS} \mathrm{304}$ & 361 & 0.25 & 29.0 \\
$\mathrm{SS} \mathrm{316L}$ & 286 & 1.80 & 11.5 \\
At 800 ${ }^{\circ} \mathrm{C} \mathrm{2 \textrm {h } ^ { - 1 }}$ & & & \\
$\mathrm{SS} \mathrm{304}$ & 411 & 0.31 & 27.4 \\
$\mathrm{SS} \mathrm{316L}$ & 306 & 1.45 & 5.0 \\
$\mathrm{ZrO}_{2}-304$ & 378 & 2.10 & 4.7 \\
$\mathrm{ZrO}_{2}-316 \mathrm{~L}$ & 308 & 10.40 & 3.4 \\
\hline
\end{tabular}

$286 \mathrm{mV}$, is practically the same for $304 \mathrm{SS}$ and slightly decreases for SS 316L. The results are encouraging considering that the films are thin but homogeneous.

Films of $\mathrm{ZrO}_{2}$ coated on stainless steel act as a physical barrier against corrosion. The decrease, by a factor of three to seven, in the corrosion rate is limited by the texture of the coating, which is still porous at the densification temperature used $\left(800^{\circ} \mathrm{C}\right)$. Higher densification temperatures, which should improve the densification, are not adequate as a $\mathrm{Cr}_{2} \mathrm{O}_{3}$ crystalline thin layer grows quickly at the metal-coating interface and cracks the inorganic coatings $[9,10,12]$. It is therefore necessary to develop compositions that may be densified fully at lower temperatures. Moreover, these coatings cannot be used on common steel because the oxidation layer already grows very fast at $\sim 200-300{ }^{\circ} \mathrm{C}$ where the coatings are still highly porous.

A much better approach has been recently developed by coating organic modified ceramic (ORMOCER) films, although these materials cannot be used at temperatures much higher than 250 $300{ }^{\circ} \mathrm{C}$. The corrosion rate in $0.5 \mathrm{M} \mathrm{H}_{2} \mathrm{SO}_{4}$ of $\mathrm{ZrO}_{2}-$ polymethyl methacrylate (PMMA) deposited on $316 \mathrm{~L}$ SS substrate is of the order of $0.13 \mathrm{mil}$ per year, a factor 30 times smaller than that of asreceived stainless steel [13]. Even better results, $\mathrm{CR}=0.005$ mil per year, have been obtained recently with $\mathrm{PMMA}-\mathrm{SiO}_{2}$ and methyl methacrylate (MMA)- $\mathrm{SiO}_{2}$.

$\mathrm{ZrO}_{2}$ coatings were synthesized using starting materials such as $\mathrm{Zr}\left(\mathrm{OC}_{3} \mathrm{H}_{7}\right)_{4}, \mathrm{C}_{3} \mathrm{H}_{7} \mathrm{OH}, \mathrm{CH}_{3} \mathrm{COOH}$ and $\mathrm{H}_{2} \mathrm{O}$ with application of ultrasound. Single dipcoated thin films of $\mathrm{ZrO}_{2}$ deposited on 304 or $316 \mathrm{~L}$ stainless steel substrates and heat-treated at high temperature are crystalline with tetragonal structure. They provide effective corrosion protection of these metals in aqueous sulphuric acid solution at room temperature. The results suggest that the surfaces exhibit corrosion resistance and passivation properties similar to those demonstrated by bulk $\mathrm{ZrO}_{2}$. The lifetime of the substrate can be increased up to a factor of seven.

\section{References}

1. O. DE SANCTIS, L. GOMEZ, N. PELLIGRI, A MARAJOFSKY and A. DURAN, J. Non-Cryst. Solids 121 (1990) 338.

2. M. GUGLIELMI, D. FESTA, P. C. INNOCENZI, P. CLOMBO and M. GOBAIN, ibid. 147, 148 (1992) 474

3. A. R. DI GIAMPAOLO, M. PUERTA, J. LIRA and N. RUIZ, ibid. 147, 148 (1992) 467.

4. K. IZUMI, H. TANAKA, Y. UCHIDA, N. TOHGE and T. MINAMI, ibid. 147, 148 (1992) 483.

5. M. ATIK and M. A. AEGERTER, ibid. 147, 148 (1992) 813.

6. P. DE LIMA NETO, M. ATIK, L. A. AVACA and M. A AEGERTER, J. Sol-Gel Sci. Technol. 1 (1994) 177.

7. M. ATIK and J. ZARZYCKL, J. Mater. Sci. Lett. 13 (1994) 1301

8. M. ATIK, C. R'KHA and J. ZARZYCKI, J. Mater. Sci Letters 13 (1994) 266.

9. P. DE LIMA NETO, M. ATIK, L. A. AVACA and M. A AEGERTER, J. Sol-Gel Sci. Technol. 2 (1994) 529 
10. M. ATIK, P. DE LIMA NETO, L. A. AVACA, M. A. AEGERTER and J. ZARZYCKI, J. Mater. Sci. Lett. 13 (1994) 1081.

11. J. O'M. BOCKRIS and A. K. N. REDDY, 'Modern Electrochemistry', Vol. 1 (Plenum Press, New York, 1970) 180.

12. M. ATIK, P. DE LIMA NETO, L. A. AVACA and M. A. AEGERTER, J. Appl. Electrochem. 25 (1995) 142.
13. M. ATIK, F. P. LUNA, S. H. MESSADEQ and M. A. AEGERTER, in Eighth International Workshop on Glasses and Ceramics from Gels, Faro, Portugal, 18-22 September 1995). 